\title{
Concepciones sobre lo divino en Lisímaco Chavarría y Jorge Luis Borges: Del universo a lo multiverso
}

\section{Conceptions about the divine in Lisímaco Chavarría and Jorge Luis Borges: From the universe to the multiverse}

\author{
Mauricio Arley Fonseca ${ }^{1}$
}

Fecha de recepción: 3-2-20

Fecha de aprobación: 14-10-20

\begin{abstract}
Resumen
El artículo parte de un interés comparativo acerca de las concepciones de lo divino, con referencia a los autores Lisímaco Chavarría y Jorge Luis Borges, cuyos textos literarios convergen con ideas comunes, y una de ellas origina esta propuesta de trabajo: Dios como fuente de lo trascendente. Esto conduce a la necesaria reflexión teórica sobre lo multiverso, con las múltiples facetas de la existencia divina. La muestra de textos literarios está compuesta por poemas, cuentos y ensayos, los cuales serán analizados a partir de aportes teóricos hermenéuticos, teológicos y literarios. En el desarrollo se presentará a Dios con distintos rostros y manifestado a través de la naturaleza, lo femenino y el Aleph. Es necesario acotar que en los textos seleccionados predomina un Dios de la tradición judeo-cristiana con algunas referencias a divinidades egipcias, mayas, incas y nórdicas.
\end{abstract}

Palabras claves: Dios, Borges, Lisímaco, ficción, multiverso.

\begin{abstract}
This article start off from a comparative interest about divines conceptions, and it takes as reference two autors Lisímaco Chavarría and Jorge Luis Borges, which literary texts converge with similar ideas, and one of those originates this work proposal: God as fountain of the transcendent. This drives to the main theoretical deliberation about the multivers, with its many faces of the divine existence. The sample of literary texts is compose by poems, tales and essays, wich Will be analyze according to theoretical inputs from Hermeneutics, Theology and Literature. In the development, God Will be expose with many faces, and manifested through nature, feminine and the Aleph. It is necessary to delimit that, in selected texts predominates a God of Jewish and Christian tradition, with some references to egyptian, mayas, incas and nordics divinities.
\end{abstract}

Key Words: God, Divine, Borges, Lisímaco, Fiction.

1 Doctor en Lenguajes y Manifestaciones Artísticas y Literarias. Docente e investigador de la Universidad de Costa Rica, Sede de Occidente, Costa Rica. Contacto: marleyfonseca@gmail.com 


\section{Introducción}

Lo diverso presenta facetas en lo sexual, étnico, cultural, literario, etc. Ya Eco, en Los mundos de la ficción, sugiere la diversidad de hechos literarios a partir de preguntas como: ¿qué pasaría si...?, y de este modo destaca que la literatura fantástica tiene: "diversos caminos ante sí" (Eco, 2002, p. 1256), donde destacan: alotopía, utopía, ucronía, metatopía.

Con respecto a lo divino (dentro de la reflexión de lo diverso), surge la referencia a un lugar, en tanto topos; el Paraíso es un espacio mítico, donde lo divino, como esencia metafísica, se materializa en un lugar revestido utópicamente. En este contexto es prioritario considerar la definición de utopía: "el mundo posible narrado es paralelo al nuestro, existe en alguna parte, aun cuando nos sea normalmente inaccesible" (Eco, 2002, p. 1256).

Sumado a lo anterior, Borges construye lugares metafísicos como Tlön, del que se dice que: "Todos los mundos y todas las realidades están contenidos en Tlön” (Marín, 2009, p. 115), y además: “... en Tlön -el planeta ordenado de la ficción de Borges- la metafísica «es una rama de la literatura fantástica»" (Alazraki, 1974, p.22). Pero así, como un territorio permite desarrollar reflexiones metafísicas, también surgen autores ficticios, entre tantos recursos, como una estrategia retórica:

... "reproducir" la enciclopedia de Tlön, sería reescribir sus mil y una páginas, tarea innecesaria pues su idéntica copia adquiriría otro sentido, como se demuestra en "Pierre Menard, autor del Quijote", ya que anula el origen, se impone como el primer texto, y así sucesivamente. (De Toro, 2008, p. 88)

En este sentido, la anulación del origen remite a lo múltiple (en tanto múltiples caminos, un multiverso de posibilidades), con sus diversas orientaciones y reproducciones. Hoy cada vez se hace más necesario salir de la ficción de unidad (opuesto a la diversidad) impuesta por los centros de poder.

Por otro lado, el poeta Lisímaco Chavarría también nos va a ofrecer un dios que se muestra inasible, tal cual un Proteo, y ese dios se origina como si fuese causa de una concepción humana, más específicamente: surgen tantos dioses como posibilidades de concebir existan, y así emergen distintos rostros, propios de la construcción latinoamericana, en un sincretismo religioso: "Dios, cualquiera que sea el aspecto que tome en la concepción humana" (Chavarría, El Pabellón Liberal, 31 de enero de 1896, contenido en Rodríguez, 2014, p.249).

Vale considerar inicialmente que los textos literarios son plurisignificativos; si situamos esta afirmación en torno al significante "Dios", este asume identidades plurales, por tanto, lo diverso de la humanidad sería expresión de lo divino, que se concibe, entre tantas posibilidades, mediante lo literario.

\section{Apuntes metodológicos}

En primer lugar, se trabajará en la construcción teórica, luego se elaborará un primer apartado de análisis de los textos de Borges y la segunda sección se dedicará de Lisímaco Chavarría, para conocer la concepción de lo divino en ambos escritores. Finalmente, se detallará aquellas coincidencias y diferencias entre ambos escritores.

Los referentes teóricos que se utilizarán para leer las propuestas literarias proceden de la hermenéutica, teología, filosofía, con el fin de distinguir distintas vías, a través de las cuales se interprete la presencia de lo divino. Para esto vale el aporte brindado por Pareyson (2014): "interpretar consiste propiamente en hacer comprensible el sentido de un discurso extraño" (p. 18), y en el caso de estudio, se trata de tomar el discurso de lo divino en textos literarios.

Debido a la naturaleza temática de lo divino, ha de considerarse la reflexión de Dios desde una perspectiva teológica:

Por muy justificados que estén teológicamente los esfuerzos actuales por «hablar de Dios» de acuerdo con los tiempos, y los intentos de traducir apropiadamente el nombre de Dios (hermenéutica), todo ello queda relativizado por 
la realidad del Dios que se revela y del que se da testimonio en ellos. Pues como quiera que nos dirijamos a Dios a base de su propia revelación («Dios», «Cristo», «Espíritu Santo», «nuestro padre», «nuestro Dios», «un Dios»), jamás se trata de nombres propios; todos ellos son más bien expresión de la exclusiva comunión del Uno con los hombres. (Coenen, Beyreuther, Bietenhard, 1985, p. 43)

A continuación, se nombran los principales textos que se analizarán en el estudio. En cuanto a Borges se presentan: La perpetua carrera de Aquiles y la tortuga (DISCUSIÓN, 1932) La doctrina de los ciclos (Historia de la eternidad, 1936). El jardín de los senderos que se bifurcan (1941), La escritura del dios (El Aleph, 1949), Diálogo de muertos (El hacedor, 1960). Por otro lado, sobre Lisímaco se estudia: La ciencia (El pabellón liberla, 1896), Espigas y azucenas (Poemas diversos, 1896-1913), Manojo de guarias (Pandemonium, 1913), Rebeldías (Desde los Andes, 1907), Apolo en la montaña (Páginas Ilustradas, 1909).

\section{Reflexiones literarias y filosóficas}

Dios ha sido matriz donde convergen voces literarias, filosóficas, científicas, teológicas, artísticas, neurológicas, etc. Por ejemplo, en Leibniz no solo se encuentran desarrollos críticos en el área matemática, sino también filosófica y teológica, y esta integración lo llevó a pensar en la existencia de una lógica universal que le permitiera interpretar el acontecer del mundo y, para ese lugar, Dios se convirtió en uno de sus referentes primordiales. De este modo, Leibniz propone una postura holística que recuerda la construcción conceptual del Aleph borgeano.

La búsqueda de la lógica universal fue una aspiración de Leibniz, quien consideraba que el cambio caracteriza a todo ser creado y a la misma mónada (sustancia simple), la cual forma parte de los compuestos. Pero, hay algo que se preserva en el cambio: "Porque como todo cambio natural se hace por grados, algo cambia y algo queda" (Leibniz, 1975 p. 29). Y el cambio se abre a un mundo en plena construcción: "Y allí donde no hay límites, es decir, en Dios, la perfección es absolutamente infinita" (Leibniz, 1975, p. 39).
La permanencia histórica se da por un registro de la memoria: esta es la característica de las almas (Leibniz, 1975, p. 32). Por otra parte, las transformaciones generan múltiples vías (en tanto versos, senderos), donde unos mundos, en vez de otros, se vuelven más afines a las condiciones de existencia:

Ahora bien, como hay una infinidad de universos posibles en las ideas de Dios y como no puede existir sino solo uno de ellos, es necesario que exista una razón necesaria de la elección de Dios, la cual la determine uno antes que a otro. Y esta razón no puede encontrarse más que en la conveniencia o en los grados de perfección que estos mundos contienen; pues cada universo posible tiene derecho a pretender la existencia en la medida de la perfección que comprende. (Leibniz, 1975, p. 44)

Esta definición de "mundos posibles" se valora desde una perspectiva holística, cuyas interacciones multiplican sentidos entre los componentes del universo, en donde se acomodan las cosas creadas de forma particular:

...hace que cada substancia simple tenga relaciones que expresen todas las demás, y que ella sea, por consiguiente, un espejo viviente y perpetuo del universo.

Y cómo una misma ciudad contemplada desde diferentes lugares parece diferente por completo y se multiplica según las perspectivas, ocurre igualmente que, debido a la multitud infinita de substancias simples, hay como otros tantos diferentes universos, que no son, empero, sino las perspectivas de uno solo, según los diferentes puntos de vista de cada mónada. Todo cuerpo se resiente de todo lo que se haga en el universo; de tal modo que aquel que lo ve todo podría leer en cada uno lo que ocurre en todas las partes, e, incluso, lo que ocurre y lo que ocurrirá [...] un Alma no puede leer en sí misma más de lo que se le representa distintamente, no sabría desplegar de una vez todos sus repliegues porque se extienden al infinito. (Leibniz, 1975, pp.44-47) 
A esto podemos agregar que las múltiples versiones dan vida a la literatura. No hay un Dios omnipotente que regule el proceso de significación. En un texto complejo, hay diversas posibilidades de resolución; es plurisignificativo. Asumir lo contrario sería un camino fundamentalista, entre cuyos adeptos: "Confunden la verdad eterna con la expresión temporal de la verdad [...] defiende la verdad teológica de ayer como si fuese un mensaje inmutable y opuesto a la verdad teológica de hoy y mañana. El fundamentalismo falla al entrar en contacto con la situación actual.” (Chaves, 1982, p. 15).

Y por otro lado, hablar de la diversidad de lo divino en vez de Dios es parte de un proceso de interpretación que transforma la figura de Dios, en lo que se conoce de su manifestación a partir de variados prismas de observación: "Las figuras divinas se espiritualizan hasta que finalmente son sustituidas por conceptos generales como «la razón del mundo», «lo divino» o «lo que es», que interviene en el mundo y lo forma en cuanto que da sentido y ordena" (Coenen, Beyreuther, Bietenhard, 1985, p.31).

En el contexto teológico, las concepciones de lo divino nos trasladan al plano de la metáfora: "Lo que se necesita en la actualidad, creo yo, son intentos de elaborar nuevos ejemplos, nuevos modelos de la fe cristiana. Esto exigirá, como exigieron las teologías del pasado, nuevas metáforas y conceptos para expresar el poder salvífico de Dios" (McFague, 1994, p.65), también vale resaltar el ligamen: Teología-Poesía-Filosofía, de ahí que esta tríada se articule del siguiente modo:

Desde la perspectiva de la teología metafórica, el teólogo se sitúa en un lugar anómalo, que participa tanto de la poesía como de la filosofía: son poetas en la medida en que deben ser sensibles a metáforas y modelos que estén en consonancia de la fe cristiana [...] y son filósofos en la medida en que deben aclarar de forma coherente, completa y sistemática las implicaciones de tales metáforas y modelos. (McFague, 1994, p.68)

A partir de las propuestas de Foucault (1996a), se distingue la función de la escritura en rumbo hacia el infinito, y se muestra marcada por la duplicación, el pliegue, el redoble: "la escritura alfabética es ya en sí misma una forma de duplicación, puesto que representa no el significado sino los elementos fonéticos que los significan" (Foucault, 1996a, p. 145). Esta reduplicación, lo múltiple, cual virus, se integra a otras superficies e inicia su reproducción simulada.

Sumado a lo anterior, vale considerar que mediante el diseño gráfico, un cuerpo nace a través del proceso de la impresión: "hace del resultado obtenido una «copia» que es el «fruto carnal», táctil, y no el reflejo atenuado de su «modelo»" (Soler y Castro, 2004, p. 97). La forma cóncava de base opera como matriz, es una conexión fiel entre pasado y presente. La forma es un patrón, molde, matriz de posteriores reproducciones; por ejemplo, las máscaras mortuorias tienen este funcionamiento.

Entonces, si bien la forma creada guarda semejanza con la matriz de la forma originaria, las condiciones del entorno pueden producir variaciones con el advenimiento de las generaciones.

Todo esto lleva a considerar que las metáforas de Dios han de recontextualizar la experiencia humana respecto de lo divino, que será analizado en textos literarios, donde un Dios diverso nos remitiría a rasgos anómalos de la tradición ortodoxa.

\section{Concepción de lo divino en Borges}

A continuación, se irán detallando distintas concepciones que Borges ha desarrollado en torno a la temática que nos atañe investigar.

Dios es un significante que está disperso en poesía, cuento, ensayo, entre títulos como: La escritura de Dios (El Aleph, 1949), La secta del Fénix (Artificios, 1949), El Golem (El otro, el Mismo, 1964), La diosa gálica (Atlas, 1984). Y claramente, a Borges no se le escapa que el sincretismo religioso se convierte en instrumento ideológico de dominación, como lo propone en La diosa gálica: "La llamarían Diana o Minerva, a la manera indiferente de los imperios que no son misioneros y que prefieren reconocer y anexar las divinidades vencidas" (Borges, 2009, p. 487). 
Dios, en tanto matriz, es verdad eterna, originaria, mientras que sus discursos son las expresiones temporales de la verdad.

...la mirada retrospectiva (la traza) agrega un nuevo texto complicando la operación y haciendo imposible el regreso a un origen, formulando un laberinto en el cual su texto es una digresión suplementaria, un falso y ciego espejo, imitando una infinita especulación, lo cual Borges denomina 'Jangr', pronunciación castellana de 'hong' que representa "un nudo difícil de desatar, un gran problema, un rompecabezas”. Los libros evocados están insertos en los textos de Borges, les son familiares, pero a la vez no se le puede reducir a estos, han dejado ya de ser ellos mismos en el nuevo contexto, han perdido su identidad. Borges agrega que si la 'igualdad' incluye la `identidad', entonces existe sólo un sujeto indivisible en el cual se encuentran todos los seres, y estos son los órganos, las máscaras de la divinidad. Si llevamos a esta argumentación a la práctica textual de Borges, vemos que se está negando el origen y acentuando la multiplicación de las trazas, aquella superficie que se unta en una tradición, pero que no la reproduce... (De Toro, 2008, pp. 87-89)

Así planteado, un sujeto indivisible, a partir del cual se encuentran todos los seres, es la representación de Dios desde una concepción topológica de una banda de Moebius: se encuentra en todos; es uno y es varios; es masculino y el femenino, etc. En este sentido, la escritura se multiplica y se distorsiona en la refracción sobre espejos: "las manchas de la piel son un mapa de las incorruptibles constelaciones; Judas refleja de algún modo a Jesús" (Bloom, 2004, p. 477).

Con respecto al espacio divino, Borges distingue un intento del ser humano por extraer la información total del mundo, pero en esto existe un desenlace fallido:

(con referencia al cuento Las ruinas circulares) Como su hijo soñado, también el soñador no es otra cosa que el sueño de otro mago que sueña.
La existencia de dos soñadores deja entrever la posibilidad de una serie infinita de soñadores; esta posibilidad está reforzada por la forma circular del templo (el tiempo circular según el cual todas las cosas se repiten cíclicamente, es otro tópico borgeano muy frecuente), por el número de noches que el mago emplea en procrear su sueño: 1001 (recuérdese la noche DCII de Las mil y una noches: «esa noche el rey oye de boca de Shahrazad su propia historia, con lo cual queda planteada la vasta posibilidad de una repetición infinita y circular». En los innumerables sistemas teológicos y proposiciones metafísicas, Borges ve un infatigable esfuerzo del espíritu humano por comprender e interpretar el universo. La sola pluralidad de estos sistemas, a través de siglos y milenios de historia, es indicativa de su fracaso... (Alazraki, 1974 pp. 67)

Ser el sueño del otro también abre la posibilidad de convertirse en el sueño de Dios, más precisamente, esto acontece en la muerte. Por ejemplo, en Diálogo de muertos, las conversaciones entre los personajes Quiroga y Rojas enlazan la tríada muerte-sueño-Dios:

Será que no estoy hecho a estar muerto, pero estos lugares y esta discusión me parecen un sueño, y no un sueño soñado por mí sino por otro, que está por nacer todavía.

No hablaron más, porque en este momento alguien los llamó. (Borges, 2009, p. 204)

Por otro lado, ciertos textos fantásticos fungen como imágenes (o pre imágenes) de otros textos, y así hasta el infinito; o sea, un texto se convierte en el sueño de otro texto. Por ejemplo, La perpetua carrera de Aquiles y la tortuga (1932) es preimagen, con respecto a la imagen $\mathrm{La}$ doctrina de los ciclos (1936).

En el cuadro comparativo 1, la segunda columna se ha marcado en cursiva, con los textos agregados a la versión de cuatro años atrás, de la $16^{\text {va }}$ edición Emecé, 2005. 
La perpetua carrera de Aquiles y la tortuga (1932, pp.26o, 261)

[...] Para Russell, la operación de contar es (intrínsecamente) la de equiparar dos series. Por ejemplo, si los primogénitos de todas las casas de Egipto fueron muertos por el Ángel, salvo los que habitaban en casa que tenía en la puerta una señal roja, es evidente que tantos se salvaron como señales rojas había, sin que esto importe enumerar cuántos fueron. Aquí es indefinida la cantidad; otras operaciones hay en que es infinita también. La serie natural de los números es infinita, pero podemos demostrar que son tantos los impares como los pares. Al 1 corresponde el 2

$\mathrm{Al} 3$ corresponde el 4

$\mathrm{Al} 5$ corresponde el 6 , etcétera.

La prueba es tan irreprochable como baladí, pero no difiere de la siguiente de que hay tantos múltiplos de 3.018 como números hay.

Al 1 corresponde el 3018

$\mathrm{Al} 2$ corresponde el 6036

Al 3 corresponde el 9054

$\mathrm{Al} 4$ corresponde el 12072, etcétera.

Lo mismo puede afirmarse de sus potencias, por más que éstas se vayan rarificando a medida que progresemos.

$\mathrm{Al} 1$ corresponde el 3018

Al 2 corresponde el $3018^{2}$, el 9.108.324

$\mathrm{Al} 3$..., etcétera.

Una genial aceptación de estos hechos ha inspirado la fórmula de que una colección infinita -verbigracia, la serie de los números naturaleses una colección cuyos miembros pueden desdoblarse a su vez en series infinitas. La parte, en esas elevadas latitudes de la numeración, no es menos copiosa que el todo: la cantidad precisa de puntos que hay en el universo es la que hay en un metro de universo, o en un decímetro, o en la más honda trayectoria estelar...
La doctrina de los ciclos (1936, pp.412, 413)

[...] La operación de contar no es otra cosa para él [Cantor] ${ }^{2}$ que la de equiparar dos series. Por ejemplo, si los primogénitos de todas las casas de Egipto fueron matados por el Ángel, salvo los que habitaban en casa que tenía en la puerta una señal roja, es evidente que tantos se salvaron como señales rojas había, sin que esto importe enumerar cuántos fueron. Aquí es indefinida la cantidad; otras agrupaciones hay en que es infinita. El conjunto de los números naturales es infinito, pero es posible demostrar que son tantos los impares como los pares. Al 1 corresponde el 2

$\mathrm{Al} 3$ corresponde el 4

$\mathrm{Al} 5$ corresponde el 6 , etcétera.

La prueba es tan irreprochable como baladí, pero no difiere de la siguiente de que hay tantos múltiplos de tres mil dieciocho como números hay -sin excluir de éstos al tres mil dieciocho y sus múltiplos. Al 1 corresponde el 3018

$\mathrm{Al} 2$ corresponde el 6036

$\mathrm{Al} 3$ corresponde el 9054

$\mathrm{Al} 4$ corresponde el 12072 , etcétera.

Cabe afirmar lo mismo de sus potencias, por más que éstas se vayan rarificando a medida que progresemos.

Al 1 corresponde el 3018

Al 2 corresponde el $3018^{2}$, el 9.108.324

$\mathrm{Al}_{3}$...., etcétera.

Una genial aceptación de estos hechos ha inspirado la fórmula de que una colección infinita -verbigracia, la serie de los números naturales es una colección cuyos miembros pueden desdoblarse a su vez en series infinitas. (Mejor, para eludir toda ambigüedad: conjunto infinito es aquel conjunto que puede equivaler a uno de sus conjuntos parciales.) La parte, en esas elevadas latitudes de la numeración, no es menos copiosa que el todo: la cantidad precisa de puntos que hay en el universo es la que hay en un metro de universo, o en un decímetro, o en la más honda trayectoria estelar...

\section{Cuadro 1. Comparación de dos textos con referencia a números naturales. Elaboración propia.}

En las dos columnas anteriores, el texto repetido es significativo, no es un auto plagiado de Borges. Este ejercicio ofrece la posibilidad de ser leído a partir de sus líneas antecesoras: hay texto previo a ambos textos repetidos, y a ese texto antecesor y diferenciado se le llamará himen del texto compartido.

Las primeras líneas del texto seleccionado en La perpetua carrera de Aquiles y la tortuga son: "Para Russell, la operación de contar es (intrínsecamente) la de equiparar dos series" (p.26o), y estas forman parte de un párrafo que trata acerca de una refutación que hace el filósofo Russell a los argumentos de Bergson, esto con la finalidad de responder a la pregunta: “¿Por qué Aquiles adelanta a la tortuga?” (p.259).

Por otro lado, las primeras líneas del texto La doctrina de los ciclos son: "La operación de contar no es otra cosa para él [Cantor] que la de equiparar dos series” (p.412). Estas líneas forman parte de un párrafo, cuya extensión es de tres líneas adicionales y trata acerca de la teoría de conjuntos de Cantor; este aporte conceptual de Cantor permite reconocer el porqué del cambio de significante "serie" por "conjunto" en el texto donde se menciona el nombre Cantor en lugar del de Russell.

2 El nombre Cantor (entre corchetes) es un agregado mío; no se debe confundir con los usos del paréntesis que proceden de la edición original. 
También se puede entender los textos compartidos como parte de un punto de conectividad entre dos textos: uno en un universo 1 y otro en un universo 2. Por otro lado, no es casual encontrar el nombre La doctrina de los ciclos, pues precisamente hay algo que retorna cíclicamente, y por ende, se repite; entonces, lo que parece ser un plagio, podemos tomarlo como parte de una productividad del texto cíclico.

En la lectura del cuento La escritura del dios (El Aleph, 1949), Tzinacán pesquisa las manchas dejadas sobre el pelaje del jaguar. La lectura, en estas condiciones, llegará hasta donde el sujeto se siga nombrando en el orden de la diferencia, no solo como nombre propio: Tzinacán, sino también como antiguo sacerdote, entre tantas otras distinciones procedentes de la apertura con la otredad. Esto permite considerar que el otro es asidero vital para motivar la existencia de nuevos mundos, donde el reciente mundo contiene los anteriores, por una suerte de dispersión de concatenaciones, o como lo desarrolla Borges: "decir el tigre es decir los tigres que lo engendraron, los ciervos y tortugas que devoró, el pasto de que se alimentaron los siervos..." (2005, p.639).

$\mathrm{Al}$ escribir, Borges plantea simulacros: algunos fueron publicados, mientras que otros fueron olvidados (hay textos que terminan en poder de María Kodama, otros en las profundidades de lo inconsciente). Al leer a Borges, también hay simulacros que se colocan en los caminos de ficción para asentar el campamento de ideas desde algún punto creativo y orientado, pero, a pesar de que se funde este campamento, en caso de que se esté en medio del desierto (el laberinto paradigmático borgiano), el destino más certero será la muerte, pues al situarse en medio del desierto estamos ante un laberinto sin paredes: no se sabe adónde ir.

Asimismo, Dios es un simulacro con diversas expresiones. La reflexión acerca del simulacro remite a la autoría, Dios como autor, pero ¿acaso importa el autor? Borges es el primero en matar su lugar de autoría para abrir espacio a la productividad de la comunidad lectora; esto lo reconoció en entrevista televisiva en Buenos Aires: "una vez publicado un libro no me interesa" (Carrizo, 1981, p.103). Por otro lado:

\begin{abstract}
Muchos de sus cuentos presentan la idea de que la identidad del autor es irrelevante; la paráfrasis, la cita oculta, las atribuciones verdaderas y falsas fortalecen esta perspectiva sobre la propiedad y la originalidad de lo escrito que sólo responde a la situación de enunciación y de lectura [...] También Borges, como los críticos de Tlön, ha inventado autores... (Sarlo, 1998, p.158)
\end{abstract}

Las invenciones alternativas son parte de una tradición literaria; hay un placer implícito en este juego purgante: "Inventemos planetas que reemplacen a nuestro planeta, como en «Tlön, Uqbar, Orbis Tertius». Ya que no podemos responder al problema del Ser con la verdad, que nuestra respuesta sea poética" (Imbert, 1999, p.21). El trabajo de análisis consiste en indagar por qué la construcción de una alteridad causa una convocatoria en ciertas especies y no en otras, y para esto el recurso de los sueños y espejos posibilita el desplazamiento.

Muchos textos de Borges requieren que el lector porte distintos discursos, pues como señala Pineda (2010, s.p.), en su trabajo Literatura, Comunicación y Caos: "Una lectura de Jorge Luis Borges, resalta que en las producciones literarias del argentino se puede aludir al género neofantástico: suponen una nueva postulación de la realidad donde arte, cultura y ciencia se imbrican".

Ese bagaje intertextual se distingue con la reflexión que brinda Borges acerca del aleph: “Existe ese Aleph en lo íntimo de una piedra? ¿Lo he visto cuando vi todas las cosas y lo he olvidado?” (Borges, 2005, p.669). Súmese a esto que el aleph procede de los desarrollos teóricos matemáticos: "la hipótesis cantoriana del continuo (llamada Aleph-o), para teorizar sobre la dificultad de hallar un conjunto que contenga todos los infinitos conjuntos del universo y que a la vez se contenga a sí mismo" (Sagastume, 2013, p.347). Estos trabajos literarios proceden de ensayos de ideas, procesos de asimilación de diversos discursos: “...los ensayos de Borges se configuran como una indagación en la que se pretende desvelar lo oculto fundamental tras la imagen aparente" (Arenas, 1998, pp.37-39). 
La concatenación de signos abre un problema de lectura, en tanto rompe con el intento programático de linealidad en el espacio narrativo, que contiene el mismo sentido de la palabra uni-verso (un camino), como unificador; la concatenación implica dispersión por distintas vías. En este contexto, Borges recurre a la noción del tiempo infinito como uno de los recursos para desarrollar la trama de la complejidad en El jardín de los senderos que se bifurcan:

El martes, $\mathrm{X}$ atraviesa un camino desierto y pierde nueve monedas de cobre. El jueves, Y encuentra en el camino cuatro monedas, algo herrumbradas por la lluvia del miércoles. El viernes, Z descubre tres monedas en el camino. El viernes de mañana, $\mathrm{X}$ encuentra dos monedas en el corredor de su

casa. (El heresiarca quería deducir de esa historia la realidad -id est la continuidad- de las nueve monedas recuperadas). Es absurdo (afirmaba)

imaginar que cuatro de las monedas no han existido entre el martes y el jueves...

(Borges, 2005, p.468)

El texto anterior muestra una de las características de Dios: es sempiterno, disperso e integrado a la totalidad de lo existente. Su expresión X se reconoce por unos, mientras que su expresión $\mathrm{Y}$ es percibida por otros, $\mathrm{y}$ así sucesivamente hasta el infinito. No existe una sola manera de percibir a Dios, pues este se revela según las condiciones cognoscitivas, culturales y demás de quien lo busque.

\section{Concepción de lo divino en Lisímaco}

Así como en Borges la expresión de la divinidad " $X$ " se reconoce por unos, mientras que su expresión "Y" es percibida por otros, en el caso de Lisímaco, el ensayo Dios también deja muy firme que dicha entidad asume un carácter proteico: "Dios, cualquiera que sea el aspecto que tome en la concepción humana” (Chavarría, El Pabellón Liberal, 31 de enero de 1896, contenido en Rodríguez, 2014, p.249).
En cuanto al sincretismo religioso, Lisímaco versa un diálogo en el poema El Dios del inca, donde confronta la ideología dominante del español Pizarro, quien pretende destronar los dioses del Cuzco del indio Yucay: "(Pizarro) echa a tierra los ídolos de aquesas heredades, esos dioses no tienen poder ni virtud [...] (Yucay) Mi Dios jamás ha muerto y no lo ciega la ira" (Chavarría, Páginas Ilustradas, 19 de abril de 19o8, en Rodríguez, 2013a, p.81).

Como herencia modernista, la diversidad de fuentes es parte de su estructura poética, por ejemplo, en Lisímaco se presenta la: "incorporación de los lenguajes fatuos del modernismo y de sus alusiones mitológicas, pero también, junto con la oralidad popular, encuentran espacio las lenguas indígenas" (Rodríguez, 2013, p.91). Vale resaltar que desde lo latinoamericano, atender temáticas literarias requiere un pasaje por lo indígena.

Por otro lado, el cómo se concibe lo divino revela variables entre escritores. En el poema Espigas y azucenas, Rodríguez (2013) resalta: "una perspectiva materialista de la existencia, alejada de la tradición judeo cristiana y de sus argumentos trascendentes. Antes bien, el poema de Lisímaco sigue el principio biológico de la transformación de la materia y lo aplica a la muerte como renacimiento en otros seres de la naturaleza” (pp.93-94). A este poema valdría sumarle Rebeldías (Desde los Andes, 1907), donde queda en constancia que al morir, el sujeto no se reúne con Dios ni sus seres queridos, sino que: "iré bregando hasta ganar la playa donde la muerte espera a solas” (Chavarría, Páginas Ilustradas, 22 de julio de 1906, contenido en Rodríguez, 2013, p.358).

La creencia en Dios aplaca uno de los grandes temores existenciales del ser humano: la soledad. La muerte envía un anuncio angustioso de potencial vacío en soledad, pero la presencia de Dios promete la eterna compañía y amor.

Lisímaco Chavarría, además de su producción poética, en la cual se distinguen reflexiones acerca de lo divino, también se interesaba por el arte de la escultura religiosa: "Aprende a tallar imágenes que ayudarán a los fieles al avivarles su fe cristiana. Según se cuenta, por entonces su predilección se vuelca en el culto mariano, especialmente en las advocaciones dolorosas, quizás con el deseo de 
solidarizarse íntimamente con su madre. También talla imágenes religiosas en que la piel exhibe heridas abiertas y laceraciones..." (Ministerio de Cultura, Juventud y Deportes, 1978, p.4).

El interés nacionalista es otra de las facetas del poeta; más precisamente sobre lo que hoy nombramos como símbolos patrios. El estudio que Villalobos (2012, p.15) desarrolla acerca de la representación de la guaria morada en la lírica de Lisímaco Chavarría, le hace fijar su atención hacia tradiciones religiosas griegas, donde se establecía la proximidad entre lo floral y lo divino; ejemplo de esto son: la diosa griega Cloris (Flora, diosa romana), Xochiquetzal "preciosa flor de quetzal" (Chinchilla, 2010, p.275).

El libro Manojo de guarias (1913) remite a Cristo (Manojo de guarias), Santa Rita y el rezo (En el barrio), entre otros referentes religiosos. Campos (2006, p.93) comenta que este libro retrata: "diversos aspectos de esa idílica nación que los olímpicos quisieron construir". Mientras que Villalobos (2012, p.17) resalta que con el libro: "Lisímaco logra institucionalizar la guaria morada como flor costarricense".

Sumado al simbolismo de la flor, vale acotar que dentro de la tradición azteca se presenta la expresión ín xóchitl ín cuícatl, flor y canto: "esto es la poesía misma, el simbolismo, y lo que se entendería hoy por arte" (LeónPortilla, Shorris, 2004, p.43), y en este contexto también se asocia con la divinidad:

Habremos de dejar los bellos cantos,

Habremos de dejar las bellas flores.

Por ello me aflijo,

Son tus cantos, Dador de vida,

Habremos de dejar los bellos cantos.

Echan renuevos las flores

Reverdecen, se entretejen, brotan.

De tu interior brota la flor del canto.

(Canto florido, en Cantares mexicanos)
Otra flor dio origen a un libro de Lisímaco: Orquídeas (1904), y en este, Villalobos (2012, p.16) resalta que aparecen las flores junto con aves y el mismo Apolo (divinidad solar):

El poeta ensalza en esta primera incursión a las orquídeas blancas. Las dibuja como parte de un escenario bucólico, junto a cascadas, peñascos y una exuberante vegetación. En esta composición paisajística hay referencias a aves como el quetzal y la alondra, e incluso, como parte del simbolismo modernista de tradición grecolatina que cultivara Lisímaco, en medio de la estampa, surge la figura de Apolo, como representación solar.

Asimismo, lo floral convive con la muerte:

El poeta se apega a la vida, sin dejar de mirar la muerte, pero la muerte es también vida. Es por ello que la huesa se transforma en flores. La poesía de Lisímaco Chavarría resuelve el dilema existencial del tánatos y el eros, conjuntándolos en la aporía de los huesos floreciendo.

(Villalobos, 2012, p.16)

Lo anterior revela que una reflexión sobre lo divino ha de pasar por los imperios de la muerte. Carvajal (2012, p.20) señala este interés por la muerte, en tanto transmigración y transformación como rasgos modernistas, para lo cual, Carvajal destaca el poema "Espigas y azucenas", además del texto "Canción de la muerte", donde el poeta dialoga con la muerte misma, en la forma de un esqueleto que guardaba en su habitación: "ella me ha enseñado a despreciar la vida viviéndola y me ha dicho en su lenguaje misterioso que la muerte de la materia humana no es más que un fenómeno de transformación, que el Cosmos es infinito, que el Universo nunca muere" (Chavarría, Páginas Ilustradas, 12 de agosto de 1906, contenido en Rodríguez, 2013a, p.467).

En síntesis, si lo floral se desprende de lo divino, y lo floral convive con la muerte, también vale agregar que la ciencia es causada por gracia divina, por lo que consecuentemente la ciencia está permeada por la muerte. Una muestra de 
lo anterior es el poema "La ciencia" (El Pabellón Liberal, el 21 de octubre de 1896), y para muestra una estrofa:

Hermosa y grande cual deidad divina, del infinito descendiste en fausto día, pedestal de la gloria y del progreso,

la verdad es tu norma, la virtud tu guía. (Rodríguez, 2014, p.138)

Como acota Rodríguez (2016, p.4): "Este carácter deífico de la ciencia concibe tal actividad no en tanto práctica social, sino más bien como efecto de iluminación cuyas verdades son transmitidas al ser humano desde un repositorio celestial". A lo anterior se suma el poema: "Apolo en la montaña” (Chavarría, Páginas Ilustradas, 1 de diciembre de 1909).

Allá en la soledad del bosque, un día

el Dios del Verso desnudose el alma

y en el silencio de la agreste calma

su lira, entre los árboles tañía. (Rodríguez, 2013a, p.172)

Y a partir de este poema, Carvajal (2012, p.20) analiza que Lisímaco: "Confiere a la poesía el acto creador. Podemos observar cómo el poeta logra comunicar con gran fuerza la idea de emoción o pasión por la poesía, cuando dice: el Dios del Verso desnudose el alma”. Además, Carvajal observa que citar a Apolo es una muestra más del cosmopolitismo, propio de los modernistas, y precisamente en el aporte de Lisímaco a la lírica modernista costarricense se resaltan: "el culto al espíritu y el sincretismo cultural" (Carvajal, 2012, p.22). Asimismo, la imagen de lo divino, dentro de la expresión poética de Las danzas guerreras, presenta todo un sincretismo cultural en el nombre de Dios: "Jehová de indio Nahua” (Chavarría, Páginas Ilustradas, 1 de marzo de 1908, contenido en Rodríguez, 2013 ${ }^{\mathrm{a}}$, p.79).

Pero en Lisímaco no solamente encontramos referencias particulares de Dios en su producción literaria, sino que él mismo ha observado, de manera crítica, algunas funciones sociales en Costa Rica, que las ha comparado con expresiones de lo divino. Por ejemplo, tal como lo ha destacado Rodríguez (2016, p.10o): "La labor periodística la estima un apostolado antes que un trabajo [...] compara el trabajo del periodista con la prédica de Jesús, quien expresaba sus consejos con sabiduría", esto lo plantea a partir del ensayo El periodista (1902), en donde afirma que: "El periodista [...] debe como Jesús predicar con la verdad humilde, pero no con el sarcasmo [...] ¡Oídlo desde la atalaya de la prensa dando con toda la fuerza de los pulmones la voz de alerta!" (2014, pp.255-256).

Vale recordar que uno de los ensayos de Lisímaco se llama Dios:

\section{¡Problema misterioso!}

El espíritu humano en estrecho pensamiento se ofusca; la inteligencia templada al calor de la instrucción pierde su gravedad, oscila, cae en la inercia, al examinar, al querer zanjar de lleno este arduo como extenso problema. ¡Dios!” ( $E l$ Pabellón Liberal, 31 de enero de 1896)

Y de este modo se evidencia que para Lisímaco hay algo inabarcable acerca de Dios, lo cual recuerda aquel cierre del Tractatus lógico-philosophicus de Wittgenstein (1973): "De lo que no se puede hablar, mejor es callarse" (p.203).

\section{Conclusiones}

Las concepciones de lo divino en la escritura de Lisímaco y Borges se encuentran en diversas categorías de análisis. A continuación, se detallan los intertextos mitológicos: en Lisímaco están presentes fuentes egipcias, griegas, entre otras: "¿Tu Dios fue el sol? ¿Amaste el cocodrilo como el hijo de Osiris?” (Palabras de la momia. Poema indígena, 1910); "Del triste Laocoonte la amargura revela de su cuerpo los dolores” (Laocoonte, Orquídeas, 1904).

En Borges aparecen mitos babilónicos, cristianos, griegos: "Ese libro cíclico es Dios [...] La Biblioteca existe ab aeterno" (La biblioteca de Babel, El jardín de los senderos que se bifurcan, 1941); "Cuando el Juicio Universal retumbe en las trompetas" (Del infierno y del cielo, El otro, el mismo, 1964); "Zeus no podría desatar las redes de piedra que me cercan” (El laberinto, Elogio de la sombra, 1969). 
Por otra parte, en cuanto a la escritura en distintos géneros y el ensayo, en Lisímaco se presenta la enseñanza en Costa Rica (El Centinela, 1 de julio de 1904), Exposición en la Escuela de Bellas Artes (La Prensa Libre, 23 de marzo de 1904), Dios (El Pabellón Liberal, 31 de enero de 1896). Mientras que en Borges: De las alegorías a las novelas (Otras inquisiciones, 1952), La poesía / El budismo (Siete noches, 1980).

En el área de poesía, En Lisímaco se puede apreciar versos calve como: "Mi Dios jamás ha muerto y no lo ciega la ira" (Chavarría, Páginas Ilustradas, 19 de abril de 1908), “Tú das savia a las vides” (Chavarría, Páginas Ilustradas, 24 de mayo de 1908). Mientras que en Borges (2009): "Dios quiere andar entre los hombres y nace de una madre" (Juan I, 14). p.314).

En relación con las metáforas de Dios, en Lisímaco Dios se expresa como arte: " Salve, divino don! En tu santuario las mentes que señalas se iluminan" (El Arte, Desde los Andes, 1907); un dios solar: "¿Tu Dios fue el sol?” (Palabras de la momia. Poema indígena, 1910); Dios agrícola: "maduras los duraznos, las fresas y las piñas” (Padrenuestro al Sol, Páginas Ilustradas, 24 de mayo de 1908). Mientas que en Borges, Dios se exhibe como femenina: "La llamarían Diana o Minerva" (Atlas, 1984); en un plano onírico: "Será que no estoy hecho a estar muerto, pero estos lugares y esta discusión me parecen un sueño, y no un sueño soñado por mí sino por otro" (Diálogo de muertos, El hacedor, 1960); es un aleph: "¿Existe ese Aleph en lo íntimo de una piedra? ¿Lo he visto cuando vi todas las cosas y lo he olvidado?” ( $E l$ aleph, 1949).

Finalmente, en cuanto al materialismo o trascendencia, Lisímaco asume una posición materialista cuando expresa: "la caduca materia se transforma / en ser nuevo, en rosales o en esencia” (Espigas y azucenas, Páginas Ilustradas, 1 de noviembre de 1909), y en ese mismo poema se advierte la muerte del ser, en tanto entidad metafísica, ese hálito del espíritu: "las penas, las cuales finan cuando el ser ha muerto". Pero el mismo Lisímaco ha mostrado su compasión hacia las personas ateas, pues estas no se percatarían de la acción creadora de Dios en todo lo existente; Dios se manifiesta desde el diminuto insecto hasta la más esplendorosa constelación: "El ateo, ese ser sin conciencia y desgraciado, ¿acaso no tiene abierto ante su vista ese gran libro de la Naturaleza?" (Dios, El Pabellón Liberal, 31 de enero de 1896).

En el caso de Borges y: la noción de Dios es de eternidad, a través de él, los jardines se bifurcan en distintos senderos, el tiempo suyo contiene todos los tiempos posibles, y asimismo, tan diversos rostros. La rosa que no se marchita (inmarcesible) es eterna, rosa del jardín del Edén, expresión de Dios mismo en su eternidad:

De las generaciones de las rosas

Que en el fondo del tiempo se han perdido

Quiero que una se salve del olvido...

Una rosa y Milton, en El otro, el mismo (1964). Borges, 2009, p.312) 


\section{Bibliografía}

Alazraki, J. (1974). La prosa narrativa de Jorge Luis Borges. $2^{\mathrm{a}}$ edición. Madrid: Editorial Gredos.

Arenas, M. (1998). La abducción creativa en los ensayos de Borges. Revista Variaciones Borges 5 (versión en disco compacto).

Bloom, H. (2004). El canon occidental. Barcelona: Editorial Anagrama.

Borges, J. (2005). Obras completas. Tomo I. Buenos Aires: Emecé Editores.

(2007). Obras completas. Tomo IV. Buenos Aires: Emecé Editores.

(2008). Inquisiciones. Madrid: Alianza Editorial.

(2009). Obras completas. Tomo II. Buenos Aires: Emecé Editores.

(2009a). Obras completas. Tomo III. Buenos Aires: Emecé Editores.

Campos, M. (2006). La transformación de la identidad o cómo lanzar una vaca del Olimpo. Káñina, Revista de Artes y Letras, XXX (2). Universidad de Costa Rica, pp. 91-101.

Carrizo, A. (1981). Borges el memorioso, en Cuadernos Hispanoamericanos. (1992). Homenaje a Jorge Luis Borges, nos 505/507. Madrid.

Carvajal, M. (2012). Lisímaco Chavarría y su aporte a la lírica costarricense. Repertorio americano, no 22, enero-diciembre.

Chinchilla, K. (2010). Conociendo la mitología. San José: Editorial de la Universidad de Costa Rica.
Coenen, C., Beyreuther, E., Bietenhard, H. (1985). Diccionario teológico del Nuevo Testamento. Vol. II. $2^{\text {a }}$ edición. Salamanca: Ediciones Sígueme.

De Toro, A. (2008). Borges infinito. Borges virtual. New York: Hildesheim.

Deleuze, G. (1988). El pliegue. Leibniz y el Barroco. Buenos Aires: Paidós.

Eco, U. Los mundos de la ficción, en Heras, E. (compilador). (2002). Los desafíos de la ficción. Habana: Casa Editora Abril.

Foucault, M. (1996). Hermenéutica del sujeto. Buenos Aires: Editorial Acme.

(1996a). De lenguaje y literatura. Barcelona: Paidós.

Imbert, E. (1999). Introducción. Borges en el Boletín de la Academia Argentina de Letras. Anejos del boletín. Anejo I. Homenaje a Jorge Luis Borges. Buenos Aires.

Leibniz, G. (1975). Monadología. 6ª edición. Buenos Aires: Aguilar.

León-Portilla, M., Shorris, E. (2004). Antigua y nueva palabra. Antología de literatura mesoamericana. Desde los tiempos precolombinos hasta el presente. México: Editorial Aguilar.

Marín, N. (2009). Los senderos trifurcados del deseo. México D.F.: Ediciones y Gráficos Eón.

McFague, S. (1994). Modelos de dios. Teología para una era ecológica y nuclear. Bilbao: Editorial Santander.

Ministerio de Cultura, Juventud y Deportes. (1978). Lisímaco Chavarría. Biografía y bibliografía. Comisión nacional de conmemoraciones históricas. San José, Costa Rica. 
Pareyson, L. (2014). Verdad e interpretación. Madrid: Ediciones Encuentro.

Pineda, A. (2010). Literatura, Comunicación y Caos: Una lectura de Jorge Luis Borges (1 parte). Revista internacional digital del grupo de investigación en teoría y tecnología de la comunicación, año III, junio, no 10. Universidad de Sevilla. Manuscrito.

Rodríguez, F. (2016). La poesía inicial de Lisímaco Chavarría: el primer período Rosas Corrales (1896-1904). Hispanic Poetic Review, vol.11, no. 2.

(2014). Lisímaco Chavarría, antología: poesía, narrativa y ensayo. San José: Editorial de la Universidad de Costa Rica.

(2013). Obras completas. Lisímaco Chavarría, tomo I. San José: Editorial de la Universidad de Costa Rica.

.. (2013a). Obras completas. Lisímaco Chavarría, tomo II. San José: Editorial de la Universidad de Costa Rica.

(2016). La ensayística de Lisímaco Chavarría, Revista Filología y Lingüística, 42 (2). San José: Universidad de Costa Rica.

Sagastume, J. (2013). El secreto de los flamencos: Andahazi, Borges y las matemáticas. Bulletin of Spanic Studies. Liverpool University Press.

Sarlo, B. (1998). Borges, un escritor en las orillas. Buenos Aires: Espasa Calpe.

Soler, A. y Castro, K. (2004). Inter(medios). La matriz intangible. Vigo: Universidad de Vigo.

Vásquez, M. (2002). Fundamentos teóricos para una interpretación crítica de la literatura infantil. Revista Comunicación, 12, 23, 2. Instituto Tecnológico de Costa Rica.
Villalobos, C. (2012). Construcciones simbólicas de la guaria morada en la poesía de Lisímaco Chavarría. Káñina, Revista de Artes y Letras, XXXVI (2). Universidad de costa Rica, pp. 15-20.

Wittgenstein, L. (1973). Tractatus Logico-Philosophicus. Madrid: Editorial Alianza. 